\title{
Infrared analysis of the bulk silicon-hydrogen bonds as an optimization tool for high-rate deposition of microcrystalline solar cells
}

\section{Citation for published version (APA):}

Smets, A. H. M., Matsui, T., \& Kondo, M. (2008). Infrared analysis of the bulk silicon-hydrogen bonds as an optimization tool for high-rate deposition of microcrystalline solar cells. Applied Physics Letters, 92(3), 0335061/3. [033506]. https://doi.org/10.1063/1.2837536

DOI:

$10.1063 / 1.2837536$

Document status and date:

Published: 01/01/2008

\section{Document Version:}

Publisher's PDF, also known as Version of Record (includes final page, issue and volume numbers)

\section{Please check the document version of this publication:}

- A submitted manuscript is the version of the article upon submission and before peer-review. There can be important differences between the submitted version and the official published version of record. People interested in the research are advised to contact the author for the final version of the publication, or visit the DOI to the publisher's website.

- The final author version and the galley proof are versions of the publication after peer review.

- The final published version features the final layout of the paper including the volume, issue and page numbers.

Link to publication

\footnotetext{
General rights

- You may freely distribute the URL identifying the publication in the public portal. follow below link for the End User Agreement:

www.tue.nl/taverne

Take down policy

If you believe that this document breaches copyright please contact us at:

openaccess@tue.nl

providing details and we will investigate your claim.
}

Copyright and moral rights for the publications made accessible in the public portal are retained by the authors and/or other copyright owners and it is a condition of accessing publications that users recognise and abide by the legal requirements associated with these rights.

- Users may download and print one copy of any publication from the public portal for the purpose of private study or research.

- You may not further distribute the material or use it for any profit-making activity or commercial gain

If the publication is distributed under the terms of Article $25 \mathrm{fa}$ of the Dutch Copyright Act, indicated by the "Taverne" license above, please 


\title{
Infrared analysis of the bulk silicon-hydrogen bonds as an optimization tool for high-rate deposition of microcrystalline silicon solar cells
}

\author{
A. H. M. Smets, ${ }^{\text {a) }}$ T. Matsui, and M. Kondo \\ Research Center for Photovoltaics, National Institute of Advanced Industrial Science and Technology \\ (AIST), Central 2, 1-1-1 Umezono, Tsukuba, Ibaraki 305-8568, Japan
}

(Received 19 November 2007; accepted 22 December 2007; published online 24 January 2008)

\begin{abstract}
It is demonstrated that the signature of bulk hydrogen stretching modes in the infrared of microcrystalline silicon $(\mu \mathrm{c}-\mathrm{Si}: \mathrm{H})$ deposited at high deposition rates can be used for solar cell optimization in the high pressure depletion regime. A relation between the performance of a $p-i$ - $n$ solar cell and the hydride stretching modes corresponding to hydrogenated crystalline grain boundaries is observed. These crystalline surfaces show postdeposition oxidation and the absence of these surfaces in the $\mu \mathrm{c}-\mathrm{Si}: \mathrm{H}$ matrix reflects device grade microcrystalline material. (C) 2008 American Institute of Physics. [DOI: 10.1063/1.2837536]
\end{abstract}

In general, device grade microcrystalline silicon $(\mu \mathrm{c}-\mathrm{Si}: \mathrm{H})$ properties are obtained in a narrow deposition parameter window close to the conditions at which the growth leading to the amorphous silicon $(a-\mathrm{Si}: \mathrm{H})$ phase transfers to the $\mu \mathrm{c}-\mathrm{Si}: \mathrm{H}$ phase. ${ }^{1,2}$ Device grade $\mu \mathrm{c}-\mathrm{Si}: \mathrm{H}$ can be classified as dense $\mu \mathrm{c}-\mathrm{Si}: \mathrm{H}$ without any significant postdeposition oxidation, as bulk oxidation is linked to a reduction in the red response of the $p-i-n$ device. ${ }^{3-5}$ The most characteristic properties of $\mu \mathrm{c}-\mathrm{Si}: \mathrm{H}$, such as microstructure, crystallinity, grain size, defects, and conductivity, have been extensively studied by Raman spectroscopy, 6,7 X-ray diffraction, ${ }^{7,8}$ transmission electron microscopy, ${ }^{8}$ electron spin resonance, ${ }^{9}$ and optoelectronic characterization techniques. ${ }^{10,11}$ However, these easy-to-use analyze techniques are not able to unambiguously determine whether a deposited film is in the good narrow parameter window. The only reliable qualification of "device grade" material is the time-consuming procedure of the integration of an intrinsic film in a $p-i-n$ device. Furthermore, the parameter window for device grade $\mu \mathrm{c}-\mathrm{Si}: \mathrm{H}$ becomes narrower for the industrially interesting high deposition rate $(>2 \mathrm{~nm} / \mathrm{s})$ conditions in the high pressure depletion (HPD) (4-25 Torr) regime. ${ }^{3-5}$ As a result, easy optimization strategies of $\mu \mathrm{c}-\mathrm{Si}: \mathrm{H}$ material properties, without the necessity to integrate every film in to $p-i-n$ devices, are highly desirable to reduce the time consuming optimization process. Here, we will demonstrate that the unwelcome incorporation of crystalline grain boundaries can easily be detected using infrared (IR) spectroscopy and that this observation can be used as a simple and fast optimization for the properties of high-rate deposited $\mu \mathrm{c}-\mathrm{Si}: \mathrm{H}$. We demonstrate this on $\mu \mathrm{c}-\mathrm{Si}: \mathrm{H}$ deposited by two different high-deposition-rate setups in the very high frequency (VHF)-HPD regime, the first setup using a conventional showerhead electrode ${ }^{3}$ (SE) and the second setup using a multi-hole-cathode (MHC) electrode. ${ }^{12}$

The solar cells deposited by SE-VHF and its corresponding SE-VHF conditions A and B (see Table I) have been reported earlier in detail in Ref. 3. The $\mu \mathrm{c}-\mathrm{Si}: \mathrm{H}$ deposition conditions ( $\mathrm{C}$ up to $\mathrm{G}$ ) for the MHC-VHF setup correspond to a pressure of 10 Torr, VHF $(80 \mathrm{MHz})$ power density of $1.3 \mathrm{~W} / \mathrm{cm}^{2}$, electrode gap of $7 \mathrm{~mm}$, substrate temperature of

${ }^{a)}$ Electronic mail: arno.smets@ aist.go.jp.
$180{ }^{\circ} \mathrm{C}$, silane flow of $12 \mathrm{SCCM}$ (SCCM denotes cubic centimeter per minute at STP) under various hydrogen dilutions. Silane profiling was used during the initial $40 \mathrm{~s}$ of the deposition for conditions $\mathrm{C}$ up to $\mathrm{G} .{ }^{13}$ The films are integrated in a solar cell structure of glass/ $\mathrm{ZnO} / p-i-n / \mathrm{ZnO} / \mathrm{Ag}$ with an active area of $0.25 \mathrm{~cm}^{2}$. Films with a thickness of $1.8 \mu \mathrm{m}$ have been deposited on IR transparent $c$-Si samples for the IR analyses in transmission mode (Perkin Elmer, FT-IR Spectrum 2000). Note that for the depositions using the MHC-VHF (conditions $\mathrm{C}-\mathrm{G}$ ) compared to deposition using the SE-VHF, the texture of the $\mathrm{ZnO}$, the intrinsic film thickness $(\sim 1.8 \mu \mathrm{m}$ compared to $2.2-2.4 \mu \mathrm{m})$ and the $p$ - $i$ interface is not optimized and the solar cell structure is exposed to two vacuum breaks, one before and one after the $i$-layer deposition. Consequently, the solar cell performances of MHC-VHF conditions $C$ up to $G$ are lower than for the SE-VHF condition B (see Table I).

In Fig. 1, an IR spectrum, focused on the range of the hydride $\left(\mathrm{Si}-\mathrm{H}_{x}\right)$ stretching modes $(\mathrm{SMs})$, for $\mu \mathrm{c}-\mathrm{Si}: \mathrm{H}$ films deposited on $c$-Si, is presented and exhibits all modes which have been observed in undoped $\mu \mathrm{c}-\mathrm{Si}: \mathrm{H}$ solids so far. It is impossible to uniquely resolve all SMs using only one IR spectrum. Nevertheless, by using a large set of samples with

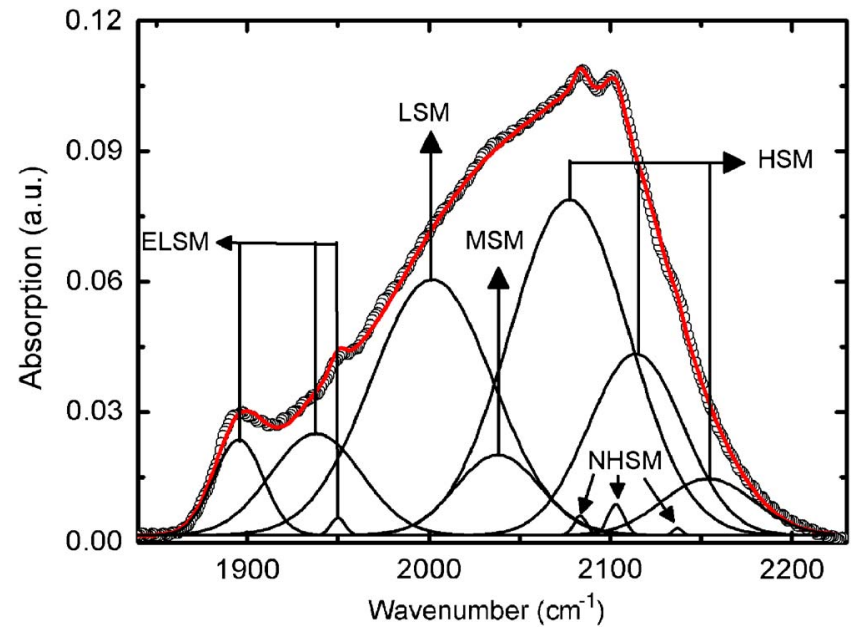

FIG. 1. (Color online) A close-up of the measured stretching modes (open circles) of $\mu \mathrm{c}-\mathrm{Si}: \mathrm{H}$ film. The lines represent the total fit and the 11 Gaussian-shaped stretching modes. 
a wide variety of hydrogenated silicon $(\mathrm{Si}: \mathrm{H})$ phases, ranging from amorphous up to highly crystalline porous material, we were able to assign a consistent set of SMs capable of fitting the wide variety of spectra measured. The SM frequency position of a hydride in the bulk depends on the unscreened eigen frequency of the hydride, local hydride density, bulk screening, and possible mutual dipole interactions of the hydrogen incorporation configuration. ${ }^{14}$ The low SM (LSM) $\left(1980-2010 \mathrm{~cm}^{-1}\right)$ and the high SM (HSM) $\left(2070-2100 \mathrm{~cm}^{-1}\right)$ originate from the $a-\mathrm{Si}: \mathrm{H}$ tissue in the bulk. ${ }^{15}$ The HSM ranges in $\mu \mathrm{c}-\mathrm{Si}: \mathrm{H}$, broadens by two additional modes $\sim 2120$ and $2150 \mathrm{~cm}^{-1}$, due to significant contribution of di- and trihydrides to the macroscopic amorphous surfaces in the bulk. Furthermore, three narrow HSMs (NHSM) $\left(2083,2103\right.$, and $\left.2137 \mathrm{~cm}^{-1}\right)$ are observed, reflecting mono-, di-, and trihydrides on crystalline surfaces ${ }^{16}$ assigned to crystalline grain boundaries in the bulk. The assignment of the extreme LSMs (ELSM) ( 1895, 1929, and $\sim 1950 \mathrm{~cm}^{-1}$ ) is still under discussion. However, to explain its rather large frequency shift with respect to the frequency of unscreened mono- $\left(2099 \mathrm{~cm}^{-1}\right)$ and dihydrides $\left(2124 \mathrm{~cm}^{-1}\right)$, these hydrogen incorporation configurations have to correspond to extreme high local hydride densities combined with mutual hydride dipole-dipole interactions. ${ }^{14}$

First, we consider the NHSMs reflecting hydrogenated crystalline surfaces, which are dominantly present in less dense $\mu \mathrm{c}-\mathrm{Si}: \mathrm{H}$ with a high crystallinity. The IR spectra of such $\mu \mathrm{c}-\mathrm{Si}: \mathrm{H}$ film, deposited under high hydrogen dilution and power conditions, are depicted in Fig. 2 as deposited, 10 days, and 10 months after deposition. Figure 2(a) shows the dihydride bending modes at $840-890 \mathrm{~cm}^{-1}$ and the $\mathrm{Si}-$ O-Si SMs at $950-1200 \mathrm{~cm}^{-1}$ and Fig. 2(b) shows the hydride SM absorption. The increase in the $\mathrm{Si}-\mathrm{O}-\mathrm{Si} \mathrm{SMs}$ show that the $\mu \mathrm{c}-\mathrm{Si}: \mathrm{H}$ film significantly oxidizes in the bulk due to the exposure to ambient air. Simultaneously, the intensity of the NHSMs reduces under air exposure and completely disappears within a few months, while a mode at $2250 \mathrm{~cm}^{-1}$ shows up. This latter mode corresponds to the hydride $\mathrm{O}_{x} \mathrm{Si}_{-} \mathrm{H}_{y}$ vibration with oxygen atoms back bonded to the silicon atom. ${ }^{17}$ These trends reflect that the bulk oxidation occurs at least at the crystalline grain boundaries by most probably water ${ }^{17}$ and that the crystalline $\mathrm{Si}-\mathrm{H}_{x}$ surfaces are fully transferred to $\mathrm{O}_{x} \mathrm{Si}-\mathrm{H}_{y}$ surfaces. This suggests that all crystalline grain boundaries have to be surfaces in an interconnected pore and crack network which ends up at the top surface of the $\mu \mathrm{c}-\mathrm{Si}: \mathrm{H}$ film.

In Table I, the performances of the solar cells deposited under conditions $A$ up to $G$ are presented. Condition A results

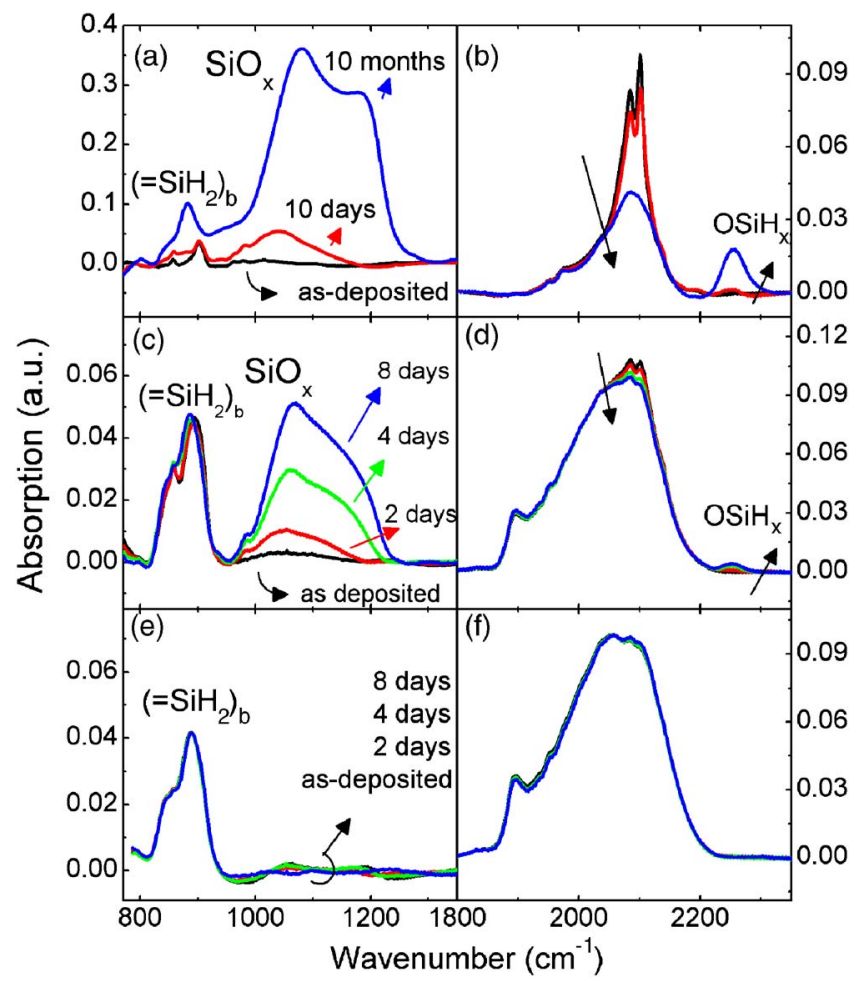

FIG. 2. (Color online) (a) and (b) depict the measured Si-O-Si SMs and the hydride SMs for porous highly crystalline $\mu \mathrm{c}-\mathrm{Si}: \mathrm{H}$ as deposited, 10 days, and 10 months after deposition. (c) and (d) depict the Si-O-Si modes and the hydride SMs for condition A, whereas (e) and (f) depict condition B as deposited, 2 days, 4 days, and 8 days after deposition.

in $p-i-n$ efficiency of $4.5 \%$ at $2.0 \mathrm{~nm} / \mathrm{s}$, while a slight modification of the deposition parameters in to condition B results in good cell efficiency of $9.1 \%$ at $2.3 \mathrm{~nm} / \mathrm{s}^{3}$. The difference in material properties between conditions $\mathrm{A}$ and $\mathrm{B}$ is also reflected in the SMs, as depicted in Figs. 2(c)-2(f), respectively. The as-deposited film of condition A still reflects a small signature of NHSMs which disappears in 8 days, accompanied with the appearance of the $\mathrm{O}_{x} \mathrm{Si}-\mathrm{H}_{y}$ mode at $2250 \mathrm{~cm}^{-1}$. The presence of a significant postdeposition oxidation is also reflected by the increase in the $\mathrm{Si}-\mathrm{O}-\mathrm{Si} \mathrm{SMs}$. In contrast, in the as-deposited high quality film of condition $\mathrm{B}$, the NHSMs are absent and no postdeposition oxidation is observed, reflecting a denser bulk matrix and the absence of hydrogenated crystalline grain boundaries in the pore network. Furthermore, for the Si:H phase in which the NHSMs are just absent, the total integrated area under the ELSM, LSM, and MSM has its maximum. In our interpretation, this

TABLE I. Illuminated $J-V$ parameters of the $p-i-n$ devices with the $i$-layer deposited under conditions A up to $\mathrm{G}$. The crystalline fraction $X_{c}$ is determined from Raman measurements of $\mu c-\mathrm{Si}: \mathrm{H}$ deposited on Corning glass under conditions $\mathrm{C}$ up to $\mathrm{G}$.

\begin{tabular}{lllllllll}
\hline \hline & & $\begin{array}{l}\mathrm{H}_{2} \\
(\mathrm{SCCM})\end{array}$ & $\begin{array}{l}R_{d} \\
(\mathrm{~nm} / \mathrm{s})\end{array}$ & $\begin{array}{l}X_{c} \\
(\%)\end{array}$ & $\begin{array}{l}V_{\mathrm{oc}} \\
(\mathrm{V})\end{array}$ & $\begin{array}{l}J_{\mathrm{sc}} \\
\left(\mathrm{mA} \mathrm{cm}^{-2}\right)\end{array}$ & $F F$ & $\begin{array}{l}\eta \\
(\%)\end{array}$ \\
\hline A & SE+opt. TCO & 670 & 2.0 & & 0.467 & 15.5 & 0.62 & 4.5 \\
$\mathrm{~B}$ & SE+opt. TCO & 670 & 2.3 & & 0.528 & 23.7 & 0.73 & 9.1 \\
$\mathrm{C}$ & MHC & 1200 & 1.6 & $80 \pm 3$ & 0.435 & 20.1 & 0.65 & 5.7 \\
$\mathrm{D}$ & MHC & $1200 \rightarrow 600$ & 1.7 & $73 \pm 3$ & 0.497 & 20.6 & 0.68 & 7.0 \\
$\mathrm{E}$ & MHC & 600 & 1.8 & $69 \pm 5$ & 0.491 & 21.2 & 0.66 & 6.8 \\
$\mathrm{~F}$ & MHC & 400 & 1.9 & $70 \pm 7$ & 0.502 & 20.5 & 0.68 & 6.9 \\
$\mathrm{G}$ & MHC & 200 & 1.9 & $47 \pm 10$ & 0.518 & 18.9 & 0.65 & 6.3 \\
\hline \hline
\end{tabular}


reflects thin hydride-dense $a$-Si:H tissue, which either passivates the crystalline grain boundaries or fills the small pores, to prevent any postdeposition oxidation of grain boundary surfaces. Considering the fact that these postdeposition oxidizing crystalline grain boundaries are linked with the reduction of the red response of the $p-i-n$ device, ${ }^{5}$ a significant amount of the unwelcome recombination of charge carriers generated in the crystalline grains seems to take place at these surfaces, reflecting the poor surface passivation properties of a native oxide.

An issue to be addressed is the fact that the IR analysis is performed on $\mu \mathrm{c}-\mathrm{Si}: \mathrm{H}$ deposited on IR transparent $c-\mathrm{Si}$ samples and not on glass/TCO/ $/ \mu \mathrm{c}-\mathrm{Si}: \mathrm{H}(p)$ substrates as used for the solar cells. Different substrate materials could induce different initial $\mu \mathrm{c}-\mathrm{Si}: \mathrm{H}$ growths. As the crystalline grain boundaries reflected by the NHSMs are only present in the postinitial growth zone $(>200 \mathrm{~nm})$, the relation between the IR spectrum and the solar cell performances is bulk dominated and therefore independent of the nature of the substrate. Consequently, the first optimization step of the $p-i$ interface (mainly controlling the $V_{\text {oc }}$ ) has been performed by combined IR absorption and Raman spectroscopy (to guarantee the absence of an $a-\mathrm{Si}: \mathrm{H}$ incubation) on thin films of $50-100 \mathrm{~nm}$ deposited on $c-\mathrm{Si}$ and Corning glass, respectively.

To demonstrate the generality of the approach presented above, $\mu \mathrm{c}-\mathrm{Si}: \mathrm{H}$ films deposited using MHC-VHF setup have been optimized by using the IR spectrum corresponding to condition B as a reference. The inclusion of a silane-profiling step $^{13}$ was necessary to achieve the same hydrogen signature in the IR, as the silane back diffusion during the initial growth induces a thick $a-\mathrm{Si}: \mathrm{H}$ incubation layer. This is far more critical for the MHC-VHF setup compared to the SEVHF setup, since the background volume in the MHC-VHF setup is significantly larger. Taking condition $\mathrm{D}$ as a starting point, conditions $\mathrm{C}$ up to $\mathrm{G}$ have been obtained by variation of the hydrogen dilution with the purpose to create slightly different SM signatures in the IR. Figure 3 shows that the IR spectrum of condition C exhibits NHSMs, reflecting less dense material accompanied with postdeposition oxidation (not shown). In line with the trend observed for the films deposited using SE-VHF, the solar cell deposited under condition $\mathrm{C}$ has a significant reduced performance of $\eta=5.7 \%$ in a $p-i-n$ device compared to conditions $\mathrm{D}-\mathrm{G}$, as a result of a reduced red response (not shown) and lower $V_{\mathrm{oc}}$. Going from conditions $\mathrm{E}$ up to $\mathrm{G}$, the general trend of increasing $V_{\mathrm{oc}}$ and decreasing $J_{\mathrm{sc}}$ versus decreasing hydrogen dilution is observed due to the fact that the amorphous fraction of the film becomes larger. ${ }^{8}$ This trend is also reflected in a larger contribution of the MSM and LSM to the IR spectrum for condition F. In our experience, the optimum efficiencies are only found for films having an IR signature such as conditions D, $\mathrm{E}$, and $\mathrm{F}$, independent of the deposition rate and the type of TCO substrates used.

In summary, we have demonstrated that the unique signature of the SMs of bulk hydrides in $\mu \mathrm{c}-\mathrm{Si}: \mathrm{H}$ can be used

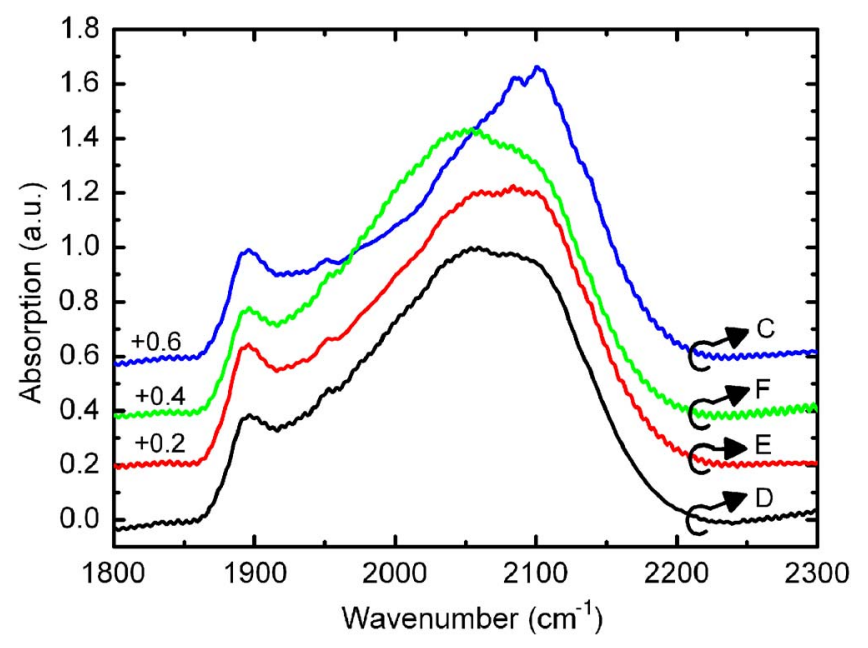

FIG. 3. (Color online) The measured hydride SMs of $\mu \mathrm{c}-\mathrm{Si}: \mathrm{H}$ films as deposited for conditions D, E, F, and C.

as an easy-to-use tool to optimize $\mu \mathrm{c}-\mathrm{Si}: \mathrm{H}$ properties at high deposition rates, without the necessity to integrate every film in a solar cell device during the film optimization process.

${ }^{1}$ R. W. Collins, A. S. Ferlauto, G. M. Ferreira, C. Chen, J. Koh, R. J. Koval, Y. Lee, J. M. Pearce, and C. R. Wronski, Sol. Energy Mater. Sol. Cells 78, 143 (2003).

${ }^{2}$ O. Vetterl, F. Finger, R. Carius, P. Hapke, L. Houben, O. Kluth, A. Lambertz, A. Müch, B. Rech, and H. Wagner, Sol. Energy Mater. Sol. Cells 62, 97 (2000).

${ }^{3}$ T. Matsui, A. Matsuda, and M. Kondo, Sol. Energy Mater. Sol. Cells 90, 3199 (2006).

${ }^{4}$ T. Matsui, M. Kondo, and A. Matsuda, Jpn. J. Appl. Phys., Part 2 42, L901 (2003).

${ }^{5}$ T. Matsui, A. Matsuda, and M. Kondo, Amorphous and Nanocrystalline Silicon Science and Technology, Materials Research Society Symposia Proceedings Vol. 808 (Materials Research Society, Pittsburgh, 2004), Paper No. A.8.1.1.

${ }^{6}$ E. Bustarret, M. A. Hachicha, and M. Brunel, Appl. Phys. Lett. 52, 1675 (1988).

${ }^{7}$ L. Houben, M. Luysberg, P. Hapke, R. Carius, F. Finger, and H. Wagner, Philos. Mag. A 77, 1447 (1998).

${ }^{8}$ J. Meier, E. Vallat-Sauvain, S. Dubail, U. Kroll, J. Dubail, S. Golay, L. Feitknecht, P. Torres, S. Fay, D. Fischer, and A. Shah, Sol. Energy Mater. Sol. Cells 66, 73 (2001).

${ }^{9}$ F. Finger, J. Müller, C. Malten, R. Carius, and H. Wagner, J. Non-Cryst. Solids 266-269, 511 (2000).

${ }^{10}$ A. Poruba, A. Fejfar, Z. Remeš, J. Špringer, M. Vaněček, J. Kočka, J. Meier, P. Torres, and A. Shah, J. Appl. Phys. 88, 148 (2000).

${ }^{11}$ J. Kočka, T. Mates, M. Ledinský, H. Stuchlíková, J. Stuchlík, and A. Fejfar, "A simple tool for quality evaluation of the microcrystalline silicon prepared at high growth rate," Thin Solid Films (2007).

${ }^{12}$ C. Niikura, M. Kondo, and A. Matsuda, J. Non-Cryst. Solids 338-340, 42 (2004).

${ }^{13}$ M. N. van den Donker, B. Rech, F. Finger, W. M. M. Kessels, and M. C. M. van de Sanden, Appl. Phys. Lett. 87, 263503 (2005).

${ }^{14}$ A. H. M. Smets and M. C. M. van de Sanden, Phys. Rev. B 76, 073202 (2007).

${ }^{15}$ A. H. M. Smets, W. M. M. Kessels, and M. C. M. van de Sanden, Appl. Phys. Lett. 82, 1547 (2003).

${ }^{16}$ V. A. Burrows, Y. J. Chabal, G. S. Higashi, K. Raghavachari, and S. B. Christman, Appl. Phys. Lett. 53, 998 (1988).

${ }^{17}$ M. Niwano, J. Kageyama, K. Kurita, K. Kinashi, I. Takahashi, and N. Miyamoto, J. Appl. Phys. 76, 2157 (1994). 